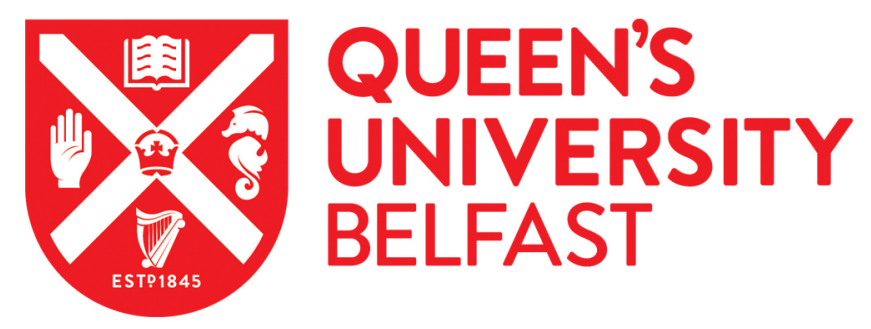

\title{
Gender, Nation, and the Politics of Shame: Magdalen Laundries and the Institutionalisation of Feminine Transgression in Modern Ireland
}

Fischer, C. (2016). Gender, Nation, and the Politics of Shame: Magdalen Laundries and the Institutionalisation of Feminine Transgression in Modern Ireland. Signs: Journal of Women in Culture and Society , 41(4), 821-843. https://doi.org/10.1086/685117

Published in:

Signs: Journal of Women in Culture and Society

Document Version:

Peer reviewed version

Queen's University Belfast - Research Portal:

Link to publication record in Queen's University Belfast Research Portal

Publisher rights

Copyright 2016 University of Chicago Press. This manuscript is distributed under a Creative Commons Attribution-Non Commercial License (https://creativecommons.org/licenses/by-nc/4.0/), which permits use, distribution and reproduction for non-commercial purposes, provided the author and source are cited.

\section{General rights}

Copyright for the publications made accessible via the Queen's University Belfast Research Portal is retained by the author(s) and / or other copyright owners and it is a condition of accessing these publications that users recognise and abide by the legal requirements associated with these rights.

Take down policy

The Research Portal is Queen's institutional repository that provides access to Queen's research output. Every effort has been made to ensure that content in the Research Portal does not infringe any person's rights, or applicable UK laws. If you discover content in the Research Portal that you believe breaches copyright or violates any law, please contact openaccess@qub.ac.uk. 


\section{Gender, Nation, and the Politics of Shame: Magdalen Laundries and the Institutionalization of Feminine Transgression in Modern Ireland}

All of us know that Irish women are the most virtuous in the world. -Arthur Griffith, founder of Sinn Féin, 1903 ${ }^{1}$

The future of the country is bound up with the dignity and purity of the women of Ireland.

—Dr. Gilmartin, Archbishop of Tuam, $1926^{2}$

There is a danger of losing the name which the chivalrous honour of Irish boys and the Christian reserve of Irish maidens has won for Ireland. If our people part with the character that gave rise to the name, we lose with it much of our national strength. . . Purity is strength and purity and faith go together. Both virtues are in danger these times, but purity is more directly assailed than faith.

-Statement of Irish Bishops, Maynooth, $1925^{3}$

W

hat is the relationship between the nation and moral purity? How has women's virtue become entangled in ideas of nationhood and national identity? The history of Ireland's transition from British rule to partitioned sovereignty in the new Irish Free State (1922) provides fertile ground for addressing such questions and for assessing the gender and sexual politics of Ireland past and present. ${ }^{4}$ The period in question was one of intense upheaval, witnessing an insurgent uprising in 1916, a War of Independence from 1919 to 1921, and a civil war from 1922 to 1923.

This article is dedicated to the survivors of Magdalen laundries and to the many advocates who have shone a light on Ireland's problematic past and present. For reading and commenting on early drafts of this work, I want to thank Clare Hemmings, Mary Evans, Dianna Taylor, and Mary McAuliffe. The article also benefited from generous comments by audiences at a public LSE research seminar and at the Class and Culture in Twentieth-Century Ireland conference in 2015. Thanks are due to the reviewers for their extremely detailed feedback and to the British Academy for funding this research.

${ }^{1}$ Cited in Ferriter $(2012,13)$.

${ }^{2}$ Irish Independent (1925); see also Luddy (2007b, 80).

${ }^{3}$ Cork Examiner (1925); see also Valiulis (1995a, 172).

${ }^{4}$ Under the Anglo-Irish Treaty, the Irish Free State was a dominion of the British Commonwealth of Nations until Ireland became a republic in 1937.

[Signs: Journal of Women in Culture and Society 2016, vol. 41, no. 4]

(c) 2016 by The University of Chicago. All rights reserved. 0097-9740/2016/4104-0005\$10.00 
Underpinning the construction of Ireland's newly emergent nation-state was a national imaginary that needed to clearly differentiate Irish identity from British identity, a task undertaken through recourse to the themes of purity, chastity, and virtue. The corollary of each of these, impurity, licentiousness, and vice, were attributed to the morally corrupt former colonizer, allowing the distinctness and superiority of Irish identity to be secured with particular reference to moral purity, bolstered by Catholic social teaching. Indeed, it has been argued that church and state, in a bid to produce and enforce a new national identity premised on moral purity, colluded to impose strict Catholic social mores and values, thereby instituting a regime of inward-looking repressiveness (Smith 2004). ${ }^{5}$ Notably, the moral purity at stake in the project of Irish identity formation was essentially a sexual purity enacted and problematized through women's bodies.

Women were saddled with the task of being guardians and upholders of virtue in the home- a sphere deemed more appropriately their domainwhile serving as symbols of the fledgling nation. As Maryann Valiulis (1995b) has argued, the emphasis on women's sexual purity as a means of forging a new national identity, itself understood as a recapturing of traditional Gaelic nationhood, went hand in hand with calls for women's return to the home. While many women had been active in nationalist, feminist, and other liberatory movements, and were promised equal citizenship in an independent Ireland in the 1916 Proclamation, the rhetoric of church and state increasingly deemed the home as more befitting of them. Given the strong normative ascription of motherhood to Irish women, where being a wife and mother was the utmost and, where possible, sole achievement of Irish womanhood, women were now recast as treacherous to their virtuous tradition. In 1924 the Irish Independent thus noted that there were mothers "who shirked or neglected their duty to their children . . . there were mothers who preferred the fashionable and crowded thoroughfare to their own quiet home: there were mothers who preferred talking on a platform or in a council chamber to chatting with their children in the nursery" (in Valiulis 1995a, 173).

While women's occupation of public space came to be seen as a dereliction of their domestic duty and potentially subversive of their symbolic caché as virtuous and pure bearers of the nation, women's bodies were deemed problematic more generally, given their capacity to be harbingers of a failure to live up to the new national identity. In other words, women's potential impurity formed a substantial threat to the project of national

\footnotetext{
${ }^{5}$ Diarmaid Ferriter (2012) warns of overstating this collusion.
} 
identity formation, which required women's purity and virtue as the essential and differentiating features of Irish nationhood.

Increasingly, then, measures ostensibly aimed at promoting Irish women's virtue and purity were introduced, and vices, often presented as English in origin, were countered through evermore punitive means. Given the ubiquitous threat posed to the national imaginary by nonadherence to national (read: Catholic) moral norms, women's sexuality and social behavior were subjected to intense scrutiny, as visible transgressions of purity, especially, were met with opprobrium and punishment. Unmarried mothers and their "illegitimate" children thus constituted a growing concern, as discourses of the need for vigilance in the face of deteriorating standards of morality abounded. Hence, while it was widely held that women somehow determined "the future of the country" with their "dignity and purity," as Archbishop Gilmartin claimed, these virtues were at the same time thought to be "in danger," thereby threatening the vision of an Ireland marked by the "chivalrous honor of Irish boys and the Christian reserve of Irish maidens" (Irish Independent 1925).

Not only was the new Ireland increasingly engaged in the production and policing of sexual mores, in enacting regressive legislation that restricted women's role in the public sphere and prescribed their place in the home, and in curtailing "foreign" corrupting influences through censorship, the new Ireland also punished and hid transgressors as threats to the moral, sexual purity that was taken to be the foundation of the nation. ${ }^{6}$ If, indeed, Ireland and its people were not exceptional in their chastity and virtue, then the new national identity had to at least be preserved by maintaining the perception that they were. Cue the ensuing culture of denial, secrecy, and hiding that marked much of church and state practice, particularly with regard to social policy and the treatment of women, children, and all those deemed to be deviant or threatening to the forging of a distinct national identity. ${ }^{7}$ It is this culture that I wish to interrogate in this article, as I explore

\footnotetext{
${ }^{6}$ For a useful table of reports and legislation regulating sexuality in the Irish Free State, see Crowley and Kitchin $(2008,356)$.

${ }^{7}$ While I think that any analysis of gender, moral purity, and national identity must be local and attend to specific historical and geographical contexts, there are parallels that can be drawn with other countries. Thus, my broad questions at the beginning of this essay should not be understood in universalist terms but are meant to prompt thinking about what those similarities across contexts might be. For instance, in Namibia much of the same rhetoric about gender and moral purity can be found in a postcolonial context where sexual immorality is ascribed to the former colonizer and to Western influences (Currier 2012). Anne McClintock's (1993) account of Afrikaner nationalism captures the moral burden placed on women who are, as in Irish nationalism, "keepers of tradition and the volk's moral and
} 
responses to the implicit threat that all women posed to the project of national identity formation. I focus particularly on the corollary to Irish women's purity, that is, their assumed shame, and the way this was addressed by hiding and physically containing women in institutions during the twentieth century. I draw on source material from recent inquiries into said institutions, as well as on research collated by advocates, survivor testimony, and historical research.

This article outlines the role shame played in pathologizing and institutionalizing women in the context of national identity formation in the early decades of the Irish state. I argue that shame was mobilized in the pursuit of a postcolonial national identity, which centrally hinged on the moral purity of women, on the one hand, but was promoted and maintained alongside constructions of women and women's potential sexual transgressions as continuous threats to that identity, on the other. This ideological instability (socially, politically, legislatively) entrenched conceptions of women, and women's bodies (as markers of visible transgression), steeped in shame - the shame those of us raised in the Catholic tradition are intimately familiar with: shame of the body, of sexuality, and particularly of women's sexual bodies. ${ }^{8}$ In order to preserve the illusion of a morally pure nation, premised primarily on women's moral purity, a vast system of increasingly punitive institutions functioned to hide women as the shamed others of the nation. Thus shame, and the hiding it ordinarily entails, operated as a disciplinary device in the project of Irish nation building as the nation covered its shame by institutionalizing women and other deviants who posed risks to a national self-understanding based on virtue and moral purity. Only in recent years have the impact and legacy of the systematic institutionalization of perceived transgressors been examined, as survivors, advocates, and government inquiries have revealed events and ideologies that gave rise to and maintained people's mass incarceration.

In what follows, I hope to productively add to the ongoing process of assessment and reflection on Ireland's past by proffering a reading of the institutionalization of women that is framed in terms of a politics of shame. I

spiritual mission" (71). The nation's virtue and (sexual) morality are thus bestowed upon women across different contexts, and transgressions of gender roles proscribed in the national imaginary are punished and deemed aberrant and disloyal of the nation. It would be interesting to see whether and how shame is employed to punish said transgression and to trace the similarities or dissimilarities in comparative work.

${ }^{8}$ That is not to assert that shame concerning gender, the body, and sexuality is solely a Catholic preserve. However, the particularly punitive response to transgression in the form of $\sin$ (which all humans are assumed to be born with) imprints sin, via shame, on us "as though it were imprinted in one's own flesh" (Hanson 1997, 37). 
believe that an analysis centered on the emotional drivers of gendered conceptions of nationhood and national identity is essential if we are to fully grasp the proliferation and functioning of institutions and their role in post-Independence Ireland. While shame has always lurked in discussions on Irish institutions - women consigned to Magdalen laundries were, after all, commonly referred to as "fallen women"-there is, to date, no explicit intellectual treatment and theorizing of shame in relation to gender, nation building, and the institutionalization of others in modern Ireland. This article will redress this analytical lacuna by making critical connections between Ireland's history, gender, and the politics of emotion and will contribute to the long-standing feminist body of work on emotion and, more recently, work done in the affective frame. ${ }^{9}$ I uniquely analyze the politics of shame with regard to gender and the mass institutionalization of women in twentieth-century Ireland in recognition of the feminist and queer theoretical insight that analyses built around affect and emotion can produce new knowledges concerning political processes, structures, and ideas (Jaggar 1992; Najafi, Serlin, and Berlant 2008). ${ }^{10}$

\section{Institutionalization: The Irish solution to an Irish problem}

Recent years have witnessed a growing interest in the gender and sexual history of Ireland, as social and feminist historians have tried to reconstruct women's and children's experiences, which had so often been excluded from official accounts and source documents (McAuliffe 2009). Moreover, there were growing suspicions, subsequently supported by government inquiries, that something was amiss with the way in which the Irish state and the religious orders (until recently in charge of running most social

9 Some feminist theorists speak of the "turn to affect," announced in the mid-1990s, while others understand a concern with affect and emotion as a continuous subject of feminist thought. For more on this, see Hemmings (2005), Clough (2007), and Gregg and Seigworth (2010).

${ }^{10}$ There is some important existing work on women institutionalized in Magdalen laundries, which this article draws on, such as Smith (2007a, 2007b). However, such work does not draw out and explicitly theorize the politics of shame in the context of women's institutionalization and the project of Irish nation building. The politics of shame is developed in the work of Sally Munt (2008), who theorizes shame in terms of what she calls "queer attachments" across a variety of contexts, including Irish contexts. She does not focus, though, on shame as it functioned in relation to the institutionalization of women in twentieth-century Ireland. Joseph Valente's (2005) work explores the connections between racialized and queer shame in Ireland under colonial rule but, while insightful in its own right, does not cover the ground of postcolonial institutionalization. 
services in Ireland) treated those in their care. Survivors' accounts of being subjected to physical, psychological, and sexual abuse in Irish institutions were mounting and were brought to the attention of national and international audiences through documentaries and mainstream films, such as Peter Mullan's The Magdalene Sisters (2002) and Stephen Frears's Philomena (2013). High-profile activists, such as Christine Buckley, formed advocacy groups, lobbied for inquiries, and gave evidence on institutional abuse, thus incontrovertibly making the case for widespread and endemic abuse in religious-run institutions that was often known to the state but ignored in a moral and legal abrogation of its responsibilities.

The Commission to Inquire into Child Abuse, set up to investigate abuses at industrial and reformatory schools and similar institutions for children from 1936 onward, found in its report (the Ryan Report) that the "deferential and submissive attitude of the Department of Education towards the Congregations compromised its ability to carry out its statutory duty of inspection and monitoring of the schools"; that the department knew that "violence and beatings were endemic within the system itself"; that it "dealt inadequately with complaints about sexual abuse," which "were generally dismissed or ignored"; and that "officials were aware that abuse occurred in the Schools and they knew the education was inadequate and the industrial training was outdated" (Ryan 2009). ${ }^{11}$ Similarly, the report of the Inter-Departmental Committee to Establish the Facts of State Involvement with the Magdalen Laundries (the McAleese Report 2013) found that these institutions were not private institutions, as hitherto maintained by officials, and that the state therefore had a responsibility toward people maintained in Magdalen institutions. This report, though refraining from tackling the question of abuse ("the committee does not make findings on this issue" [vii]), ultimately prompted a state apology from the Taoiseach (Irish prime minster) and resulted in a redress scheme for survivors.

While the McAleese inquiry has been critiqued by the survivor advocacy group Justice for Magdalenes for ignoring their submitted testimony on physical abuse and for getting the length of women's confinement wrong (based on names recorded on the electoral register; see McGettrick 2014, 2015), and the UN Committee on Torture has pointed to a lack of "many elements of a prompt, independent, and thorough investigation" (Ó Fátharta 2013), both the McAleese Report and the Ryan Report, among others, highlight the state's willingness to wash its hands of institution-

\footnotetext{
${ }^{11}$ Other investigations into child abuse were carried out on specific dioceses, resulting in Murphy, Buckley, and Joyce (2005) and Murphy (2010a, 2010b).
} 
alized women and children throughout the twentieth century. This has been confirmed even more recently by revelations concerning high mortality rates at a mother and baby home in Tuam, which has led to calls for a general investigation into this type of institution, with terms of reference published by the government in January 2015 (Irish Government 2015). ${ }^{12}$ For each of these sets of institutions, then-industrial and reformatory schools, Magdalen asylums, and mother and baby homes-there is evidence of harsh, if not extremely abusive, treatment of those kept in religious congregations' "care" and of state denial or indifference to same. Much of the state's dereliction of statutory duty toward institutionalized individuals stems, on the one hand, from the readiness of Catholic congregations to provide services the state otherwise would have had to provide (Cox 2009) and from the financial implications of such service provision while, on the other hand, I think, the state's indifference to those confined to institutions can be traced to dominant contemporaneous discourses of their deserving nature.

Insofar as Ireland's national identity was premised on moral purity and virtue, women and girls who constituted threats to this identity were constructed as bringing shame onto themselves, their families, and their nation, and were therefore deemed to be deserving of punishment and confinement. The steadfast desire to preserve the myth of Irish purity, particularly the idea, as expressed by Arthur Griffith, that "Irish women are the most virtuous in the world," necessitated the hiding of visible impurity in particular. This was borne out by evidence given in the early years of the Irish Free State to the Carrigan Committee, set up to inquire into the Criminal Law Amendment Acts 1880-85 and into Juvenile Prostitution, which resulted in a damning report undermining appeals to Irish sexual purity. ${ }^{13}$ The Carrigan Committee witnesses pointed to increases in the births of "illegitimate" children; to high instances of sexual crime, including pedophilia and incest (with correspondingly low numbers of prosecutions and inconsistencies in sentencing); and to a general moral degeneration attributed, especially by the cleric witnesses, to corrupting films, dances, and the prevalence of motorcars (which were thought to afford opportunity for sexual dalliances but also sexual assaults-as Maria Luddy

${ }^{12}$ In 2014, work by local historian Catherine Corless was revealed in the media, which documented the deaths of nearly eight hundred babies, thought to be buried in an unmarked grave at the Tuam mother and baby home in the west of Ireland. The Bon Secours Sisters ran the institution from 1925-61. See RTÉ One (2015).

${ }^{13}$ For in-depth accounts of the Carrigan Committee's work, see Smith (2004) and Ferriter (2012). 
[2007a, 198] wryly observes, “ “joy-riding’ had a very different connotation in that period than it does now").

The testimony of women's organizations, such as the Irish Women's Workers' Union and the Irish Women Doctors' Committee, tended to emphasize preventative rather than punitive measures to redress the seeming crisis in sexual mores, and in the end, the Carrigan Report made several recommendations, including that the age of consent be raised to eighteen, that the sale of contraceptives be forbidden (their advertising had already been banned), that the defense of "reasonably believing" a minor to be of the age of consent be prohibited, and, controversially, that some crimes be punished with public flogging and blacklisting (Smith 2004, 214). Significantly, the report had already excised testimony that included unfavorable comparisons with Britain (Eoin O'Duffy, commissioner of the police force, noted that "children of the poorer classes are less protected than in Great Britain"; see Smith 2004, 223; Ferriter 2012, 139), and since it constituted a record of seemingly grave moral, national failings, successive governments decided, with agreement from the Catholic Church, not to publish the report, as "the obvious conclusion to be drawn is that the ordinary feelings of decency and the influence of religion have failed in this country and that the only remedy is by way of police action. It is clearly undesirable that such a view of conditions in the Saorstat should be given wide circulation."14 Thus, the Carrigan Committee's investigation, the report, and the subsequent handling of the report are indicative of the intense secrecy required and imposed by church and state to maintain the veneer of Irish moral purity in a bid to protect the national identity. Moreover, as James Smith notes, "the political reception of the Carrigan Report-first the suppression of the report, then a legislative response [consisting of the Criminal Law Amendment Act (1935) and the Dance Hall Act (1935)]_established a precedent for church-state management of sociosexual controversies, proscribing visible manifestations of 'sexual immorality' while failing to address - or choosing to ignore-the social realities attending them" $(2004,211){ }^{15}$

\footnotetext{
${ }^{14}$ National Archives of Ireland/Department of Justice, Department of Justice Memorandum, October 28, 1932, cited in Smith $(2004,215)$. Interestingly, under the new government elected in 1932, the Minister for Justice, James Geoghegan, was advised by members of the clergy not to publish the report, with one cleric noting that it would "rejoice our enemies" (217).

${ }^{15}$ Smith describes the legislative response as a "watered-down version of what the Carrigan Report initially proposed, but one that substantially incorporated the [Catholic] hierarchy's concerns," eventually resulting in the raising of the age of consent to seventeen (church authorities had proposed eighteen); a complete ban on contraceptives; maintaining
} 
This emphasis on the visibility of immorality, then, drove church and state responses to perceived sexual transgressions and required the hiding and excising of those deemed deviant and counter to the project of nation building marked by purity and virtue. In practice, this resulted not just in repressive legislation and the curtailment of so-called vices but involved the concealment and containment of deviant others in a system of mass institutionalization. Institutionalization thus became a means of maintaining "the belief that there were no [moral] lapses . . . in Ireland," as the "Irish solution" to the problem posed by such lapses was, in the words of historian Diarmaid Ferriter, "to hide and deny those who had 'lapsed"" $(2012,6)$. The Irish solution to the Irish problem of sexual immorality, and its attendant risk of exposing a national Irish identity spuriously premised on purity, was thus to be found in an increasingly powerful network of institutions. ${ }^{16}$

\section{Institutions, shame, and contagion}

The rise of institutions, or what Michel Foucault called the "great confinement" (2001, 35), was of course not unique to Ireland. Indeed, the phenomenon can be charted in Europe across the centuries, with Foucault locating its beginning in the seventeenth-century founding of the Hôpital général in Paris. ${ }^{17}$ Nor is the intense relationship between church and state in the aftermath of World War I unusual, as parallels can be drawn with Italy in the context of a more general gendered European conservatism (Valiulis 1995a, 177) and with the Netherlands, where "both Catholic and Orthodox Calvinist groups wielded significant political power" (Ferriter 2012 , 192). In Ireland, though, the particular confluence of postcolonial nation building, the lack of a significant secular political Left (Ferriter 2012, 107), and ecclesiastical control (particularly of social services) ushered in a system of institutionalization that was especially punitive, pervasive, and persistent. Even as institutionalization was being reformed or abandoned elsewhere, Irish institutions boasted growing numbers of inmates, reaching

unlawful carnal knowledge of girls aged seventeen and younger as a misdemeanor rather than a felony; and a separate provision for the licensing of dance halls in the Dance Halls Act; see Smith $(2004,218)$.

16 The term "an Irish solution to an Irish problem" is frequently invoked with regard to the Irish state's stance on abortion, which legally prohibits women from accessing terminations (other than when their lives are at risk) but permits travel to the United Kingdom, where women can access same. See Bacik (2015) for more on this.

${ }^{17}$ For more on the merits or demerits of drawing on Foucault for analyses of sexuality in Ireland, especially with regard to the much later intensification of institutionalization in Ireland, see Inglis (1997) and Ferriter (2012). 
a high point in the 1950s with 1 in 100 per capita being confined (O'Sullivan and O'Donnell 2012). ${ }^{18}$ Between reformatory and industrial schools, mother and baby homes, a borstal (for young male offenders), prisons, psychiatric institutions, and Magdalen asylums, a staggering l percent of the population was institutionalized, despite significant emigration rates. ${ }^{19}$ This percentage was higher than the peak of penal confinement in the United States and in the Soviet Union at the time and highlights not just the interlocking nature of Irish institutions but also their longevity. Indeed, in 1966, the number of involuntary patients in Irish mental hospitals was described as "appear[ing] to be the highest in the world" (Henchy [1966] 2012).

Institutions also served specific functions, with different classes of deviants, and different threats to national moral purity, being confined accordingly. For instance, it was widely believed that hardened sinners would corrupt the still salvageable, as immorality, particularly the sexual immorality of women and girls, was understood through the prism of contagion. ${ }^{20}$ Thus, under the new Free State, a debate ensued on whether those who found themselves pregnant and unmarried for the first time should be placed alongside repeat offenders. Clerics, supposedly celibate and personally unacquainted with family life and reproductive processes, saw no irony in passing judgment and thrashing out the pros and cons of treating pregnant women as irredeemable sinners or salvageable victims, with arguments and counterarguments put forth in publications such as the Irish Ecclesiastical Record: "The 'unmarried mother' problem," as it was termed, came to be framed by the notion of a hierarchy of sinners, where "girls who 'get into trouble' ... through weakness, credulity, or folly" are contrasted with those who do so "habitually or by way of livelihood" (Sagart [1922] 2012, 45). While this debate sometimes acknowledged the stigma attached to institutionalization, especially in terms of a woman's marriage prospects- “a young man sometimes has difficulty in marrying a girl whom he knows to have been 'more sinned against than sinning,' [but] he will have the greatest repugnance to taking for his wife a girl who has been an inmate in a rescue home" (47) - a greater probing

${ }^{18}$ See Conclusion 4 in Ryan (2009).

${ }^{19}$ For more on this, see Reidy (2009).

${ }^{20}$ The idea of sinfulness and sexual immorality being contagious, and therefore in need of control and containment, should also be understood in the context of the response to venereal disease, as the nineteenth-century Contagious Diseases Acts treated women as the source of venereal disease, especially women providing sexual services to soldiers (prostitution was often presented as an English problem, presumed to fade away after colonial rule). See Luddy (2007a). 
of such stigma did not take place, with pregnancy and the visibility of moral, sexual transgression via women's bodies taken to be unquestionably shameful.

Thus, the act of hiding the blemish of pregnancy out of wedlock was seen as a service to, in the first instance, wronged or foolish first-time offenders, who wished to cover their transgression. These redeemable victims of seducers or naive country girls, "Catholic girls who fall more through folly than vice," deserved a "helping hand" (Sagart [1922] 2012, 47 ), so the argument went, not least given their potential flight to England and the danger this posed through "probable moral ruin and loss of faith" (46). The introduction of mother and baby homes, then, rested on a construction of femininity that was hierarchically ordered via perceived level of sinfulness, and at least partly prompted by a belief in the contagion of impurity and a fear of women's conversion to Protestantism if forced to flee to England or to make use of the services of "proselytizing bodies" at home (Garrett 2000, 330). Generally, first-time “offenders" were placed in mother and baby homes, while women and girls who had experienced more than one pregnancy were consigned to Magdalen laundries and the former workhouses, the county homes. Their children were usually "boarded out" to foster parents, sent to industrial schools, or adopted by Catholic families, particularly in the United States (possibly with financial gain for the religious orders). ${ }^{21}$

Throughout the debates on how to deal with unmarried mothers, the naturalness of feeling shame at one's transgression (itself made visible through women's bodies and the bodies of "illegitimate" children) and the need to cover said shame was assumed. A 1927 government report on poverty noted that "the illegitimate child, being the proof of the mother's shame is, in most cases, sought to be hidden at all costs" (Irish Government [1927] 2012, 72) while a 1938 infanticide case heard that "the shame . . . brought upon householders by the birth of an illegitimate child" was "a natural thing to try and avoid," just as it was "a natural thing to try and hide the birth of an illegitimate child" (in Ferriter 2012, 124). Nature was thus invoked to confirm gendered shame's normativity and to justify

${ }^{21}$ It is hoped that the planned mother and baby home inquiry will shed further light on this. With regard to the shaming of pregnant unmarried women, it should be noted that stigma also attached to women in other countries. For instance, in England, "respectability" mandated certain norms around pregnancy and wedlock at the time. And yet, Ireland differed with regard to the project of national identity formation in the postcolonial context, the strong promotion of Catholic values and social teaching, and the total absence of a secular Left, which resulted in a particularly punitive, gendered, religious conservatism. For more on women and "illegitimacy" in England, see Thane and Evans (2012). 
women's punishment and sometimes lengthy confinement in institutions. Moreover, the work of (middle-class) lay philanthropists and, overwhelmingly, the religious orders - whose task it was to hide the embodied shame of women and children while preserving the Catholic faith and working toward the salvation of their souls-was presented as providing services shamed women naturally required. ${ }^{22}$ Hence, in a call for "ladies" doing philanthropic work for rescue societies, a Dominican priest noted in 1925 that "on their death beds, it will be a consolation to them to think of the poor girls whom they have helped to save from a life of shame in this world and from eternal ruin in the next” (MacInerny [1925] 2012, 62).

\section{Shame and the Magdalen laundries}

The politics of shame in early twentieth-century Ireland functioned through the construction of deviant others who were presented as threats to a new national identity of purity and moral virtue. Others' potential sullying of this identity through sexual impurity was dealt with by taking control of bodies - the most immediate markers and visible evidence of moral transgression-and confining them to institutions in accordance with a hierarchy of sinfulness and impurity. Just as shame, as an emotion, involves the seemingly natural desire to hide one's perceived inadequacy, so the fledgling Irish nation-state required the hiding of those bringing national shame through sexual immorality in a system of mass incarceration. ${ }^{23}$ Indeed, the emotion of shame is usually presented as a nakedness, an exposure of what one would prefer not to have others, even imagined others, see and therefore involves concealment. When contrasted with guilt, it is often described as a blemish on one's character, an all-encompassing feeling of personal inadequacy. Guilt, on the other hand, is a more localized experience pertaining to specific actions we might feel bad about but can make amends for, through apology and other actions to set a situation that we made a mess of right. ${ }^{24}$

${ }^{22}$ For a critical analysis of the relationship between religious and lay Catholic philanthropic work and the development of convents in the nineteenth century, see Luddy (1995).

${ }^{23}$ What I refer to here as "national shame" is simply shame that manifests itself in the national imaginary, where women were thought to bring shame onto the nation through an inherent potential for sexual and moral transgression. While such anxieties foreground an intrinsic link between sexuality and shame (and women's bodies), such linking is not unique to Catholic social teaching. For example, queer activist and theorist Michael Warner (1999) takes shame to be a natural part of sexuality. The difficulty, for Warner, arises when such shame is displaced onto others to create distance between purer and less pure (sexual) agents.

${ }^{24}$ For the distinction between guilt and shame, see Nussbaum (2004), Locke (2007), and Williams (2008). 
Guilt, then, entails constructive exit strategies from self-opprobrium, while shame does not-our sole response consists of concealment rather than assessment and redressing the underlying blemish. Shame, in this sense, is postremedial. We have already accepted that there is something deeply wrong with us, something that is in some sense intrinsic to us and therefore cannot be fixed. This something, if exposed, would forever alter our relationships with others-how we are viewed by them but also how we view ourselves. Hence, shame's only response lies in hiding our inadequacy, a hiding that is often played out across our bodies in a physical and seemingly immediate manner. As Martha Nussbaum notes, "sometimes . . . our 'abnormal' weaknesses are uncovered ... and then we blush, we cover ourselves, we turn away our eyes. Shame . . . brands the face with its unmistakable signs" (2004, 173).

Parallels can be drawn here with the shame Ireland's sexual transgressors were deemed to induce in the national imaginary. Deviant others were constructed as intrinsically blemished and beyond repair and therefore in need of concealment behind the tall walls of institutions. Although some emphasis was placed on reform, particularly on the salvation of souls through prayer, work, and repentance, there are indications that some institutions hiding shamed others became increasingly punitive in the early decades of the Irish state. ${ }^{25}$ Of course, this gradual shift in the operation of such institutions was also refracted through the classification and gradation of sinners, with those viewed as particularly transgressive and threatening also deemed most deserving of punishment. Instructive, in this context, is the change Magdalen asylums underwent from when they were first established by lay women philanthropists in the eighteenth century. Named after Mary Magdalen and set up in response to the seeming escalation of visible prostitution on the streets of Dublin, in particular, such asylums were to provide relief to women and to teach skills, for example, in laundry work, lace making, and needlework. ${ }^{26}$

The Magdalen laundries formed part of a more general "rescue movement" throughout the nineteenth century and, according to Luddy, were relatively flexible during this time, as "women entered and left them on a regular basis and the institutions offered respite when few other welfare organizations would care for prostitutes" (2007a, 13). As the running of Magdalen asylums was entirely taken over by religious orders, often be-

${ }^{25}$ James Smith writes that the Magdalen asylums were "institutions founded with a philanthropic mission" but "became, by the close of the nineteenth century, more carceral than rehabilitative in nature" (2007a, 25).

${ }^{26}$ For in-depth accounts of the Magdalen asylums, see Finnegan (2004), Luddv (2007a), Smith (2007a), and McCarthy (2010). 
cause laypeople could no longer manage them, there are suggestions that, in the context of a national discourse of moral purity that deemed women's sexuality generally suspicious, the asylums became more punitive and inflexible. ${ }^{27}$ Indeed, as Luddy notes, in a climate where women's place in the public sphere was questioned and curtailed, "the problems associated with prostitution and unmarried motherhood, and the discussions around these issues, saw the sexuality of all women as suspect and in need of restraint" (2007a, 239). Given the potential threat women posed to Irish purity, especially by constituting embodied instances of shame, all women were treated as dangerous, with an inherent capacity for sexual immorality.

The assumption that all women were potential sexual transgressors shifted the burden of proof away from members of the clergy, social workers, police, and family members to facilitate, with relative ease, the incarceration and sometimes reincarceration of unwanted women and girls. Thus, women "inmates" or "penitents," as they were called in Magdalen asylums, were confined via several routes, based on various grounds, some of which are officially recorded but others, especially in the case of family placements, will never be known. Some women or girls were homeless, some had mental or physical disabilities, some were orphans, some were victims of abuse, some were on probation or remand for criminal offenses, some were rejected by foster parents when payments ceased, and some were transferred through the industrial school system (McAleese 2013, ii-iii).

There is also evidence of the hierarchical ordering of deviant others within institutions. Thus, Luddy notes that "within these homes, penitents were categorized in three groups, the ordinary penitents, Children of Mary, and the 'consecrated,' the latter also being called the 'class of perseverance'” (2007a, 108). Through hard work and piety, inmates could rise through the ranks of these categories, with the class of perseverance forming the step below the nuns themselves. Members of this class would take a religious vow, wear a habit, and commit to spending their lives in the asylum. However, although “the nuns' own ideal of austerity and holiness was offered as the ideal for the rescued penitents . . . they could never become 'real' nuns . . . although treated as children these women could never be full members of a religious family" (108). Thus, the innate blemish of shame that marked them as penitents-regardless of what class - was assumed to be lasting and in some sense irremovable. Prayer, discipline, and

\footnotetext{
${ }^{27}$ The McAleese report $(2013,45)$ disputes this, however, basing its conclusions on the length of women's confinement on records provided by the religious orders. See Justice for Magdalenes' critique noted on page 826 of this article.
} 
work were only capable of going so far in ensuring salvation and seemingly never quite enough to restore moral purity, certainly not on a par with the nuns'.

This manifestation of shame in terms of hierarchy is a fundamental part of its materialization, for, as Michael Warner (1999) argues, shame betrays a proclivity for seeking distance between a shamed subject and an other, onto whom shame becomes projected. A ranking of shamed others thus creates a chain along which shame travels to establish more or less deviant subjects. This produces competition, envy, and a jostling for position among those willing and able to compete for a higher place in the hierarchy. Of course it also affords the opportunity for manipulation by those in top position, as the reward of upward progression can be used as currency. In Magdalen laundries, though, achieving the highest ranking was never a possibility, since penitents' shameful, blemished nature necessarily had to stand in relief to the untainted nature of the nuns.

The type of work mandated by the religious orders running these asylums also has symbolic significance with regard to the supposedly stained, shameful souls in their charge. The alleged sins committed by women and girls confined in Magdalen laundries were read as stains upon their very characters and bodies, stains that could be removed (though never quite) through repentance and the backbreaking work of washing away stains from dirty laundry. The unsullied, holy, and morally intact nature of nuns was often compared with penitents', who were thought of as "soiled" pollutants (Luddy 2007a, 110). Hidden from public view, these pollutants, the nation's shamed, tried to redeem their souls by purifying not just laundry but also themselves. Ireland's politics of shame thus operated by disciplining bodies directly through confinement and enforced dangerous, exhausting work but also psychosocially, through the intense surveillance women were subject to in institutions, as well as more generally, given the threat they posed as deviant others to the dominant narrative of national self-representation. Thus, Luddy points out, the "Good Shepherd nuns who worked directly with the women were called 'surveillantes'" (2007a, 99) and were instructed never to leave penitents out of their sight. The women and girls were watched constantly, for if the nuns were to "leave them to themselves," they might be "the cause of the loss of their souls" (98).

There probably was a considerable amount of self-surveillance as well, given the threat posed by Ireland's punitive system of institutionalization and the ease with which others were shamed and ostracized. Certainly, we have ample accounts of the deleterious effects of the continuous discourse of sinfulness and shame, where inmates recount their internalization of 
shame, often with debilitating consequences. While giving evidence during the McAleese inquiry, a survivor who had been placed in a Magdalen laundry by a priest at the behest of her father said, "I could've got out after three months - my father came for me. But I was too ashamed to go home. I was put in there and it had a bad name and I'd have a bad name then too" (McAleese 2013, 957). Many women expressed this sentiment of having to hide, upon leaving, the shame of having been in a Magdalen asylum, and some traveled to other countries to begin new lives. While the politics of shame thus hid Ireland's national shame of assumed sexual transgression, it induced a fear of exposure, a sometimes lifelong need to hide one's shame of having been a penitent in a Magdalen laundry. Thus, the shaming of women by state, church, and family begot further shame that required concealment.

\section{Resisting shame}

The control of women's bodies in the early decades of the Irish state involved, according to Una Crowley and Rob Kitchin, a "disciplinary regime that . . . was highly gendered, focusing almost exclusively on the regulation and self-regulation of women," forming "a dense specialized grid . . . seeking to produce 'decent' women inhabiting virtuous spaces by limiting access to work and public spaces, confining women to an unsullied (marital) home, with the ever-present threat of new sites of reformation" (2008, 367).

Indeed, with the regulation of women's physical presence in the spheres of home, work, and politics, and, increasingly, in institutions, women would be confined to their appropriate place-both metaphorically and corporeally. Thus, the politics of shame, which required mass institutionalization as a means of preserving a desired national identity of moral purity, is worth assessing in terms of place and women's physical occupation of space. This occupation became increasingly problematized in the Irish Free State, with debates - concerning how to restrict women's presence in the public sphere, where to place unmarried mothers, how to confine repeat offenders away from physical proximity to salvageable soulsposing seemingly vital questions of national interest. And since the national interest was taken to be so closely bound with women's sexuality, and since women's embodied moral impurity posed a fundamental threat to the project of national identity formation, a restriction of their physical presence in accordance with moral classification prevailed. In response to the bodily containment of women in Magdalen asylums and other institutions-itself a means of covering and hiding the bodies of Ireland's assumed corporeal 
shame-some survivors emigrated when they could, and the constant shaming and threat of institutionalization may have prompted other women to leave (mainly for the United States or the United Kingdom). ${ }^{28}$

In her insightful study on emigration in the 1930s, Louise Ryan traces Irish women's migration patterns in the early twentieth century and assesses how the Irish press constructed women's flight from Ireland at the time. Interestingly, women already made up a majority of emigrants during the nineteenth century, and this gender ratio became even more amplified during the interwar years $(2002,54)$. While concerns aired in the press related to a fear of rural depopulation, a loss of the Catholic faith, and the immoral temptations of life in England, feminist historians have attributed the departure of young, mainly rural women setting out on a life of service to more than just economic concerns, arguing that these women left behind the inordinate strictures of Irish patriarchy (Ryan 2002, 52, 57). ${ }^{29}$ Moreover, referencing Kerby Miller (1990), Ryan notes that under British colonial rule, discourses of the "myth of exile" were promoted by nationalists citing British mismanagement of the Irish economy as the driver of Irish people into exile. Post-Independence, this myth became displaced by the "myth of holy Ireland," where Ireland's pious identity was contrasted with the sinfulness of the former colonizer $(2002,55)$. Emigration was not stemmed, though, by the Irish Free State administration, and in a bid to rationalize the perceived treacherousness of the flight to England, those leaving had to be demonized and undermined. Thus, emigrants were said not to be "leaving Ireland because they had to, they were not involuntary exiles, but instead were choosing to go in search of the 'sinful' pleasures of life in foreign cities" (55).

This presentation of emigrants' sinful motivations can be read as feeding into assumptions of "real" Irishness, as the national identity of purity was denied to those seen as traitorous for deserting Ireland in favor of the former colonial power. Indeed, the denial of complete Irish identity to emigrants is indicative of how nationalisms create subjectivities based on us and them, insider and outsider, as identities are forged in opposition to others. As Sally Munt describes it, nationalism “depends upon a homogenizing, idealizing process that tells a proud story of origins dependent upon selective denial, or repression" $(2008,59)$. For the other of nation-

${ }^{28}$ For further work on women's migration and tensions around class, sexual, and economic freedom, and perceived disloyalty to the nation, see Howes (2002) and Redmond (2008).

${ }^{29}$ That is not to claim that Irish women emigrants were not also subject to patriarchal norms and strictures when abroad nor that they were able to entirely escape the Irish version thereof. See work on repatriation by Paul Michael Garrett (2000). 
alism is always already within: women - though taking pride of place in narratives of birthing the nation (as the etymology of "nation" already betrays) and of the nation's sexual violation from outside-are constructed not as the ultimate beneficiaries of the homogenizing processes of nationalism but are seen in terms of difference. Thus, Anne McClintock explains that “despite nationalism's ideological investment in the idea of popular unity, nations have historically amounted to the sanctioned institutionalization of gender difference" (1993, 61), meaning that women are never the equal bearers of rights, political power, and resources in any nation-state.

As sexualized symbols of the nation, women's flight from Ireland, their physical withdrawal, entailed, I think, a recognition of this difference, and today this history presents us with evidence of women's resistance to dominant gender norms that were premised on sexual purity and enacted via containment and control of their bodies. As the other within Irish nationalism, women of course would have exercised whatever agency they could in the face of Ireland's politics of shame, whether that meant emigrating, escaping an institution, or simply following their desires without taking on the yoke of sinfulness and shame. ${ }^{30}$ There are stories of resourcefulness and perseverance-such as the account of a woman committed to two Magdalen laundries who screamed all night at both until she was released, or the stories of women running away in the laundry van (McAleese 2013, 958)—stories that betray a continuous wrestling with the dominant norms of femininity maintained in a postcolonial, patriarchal society. Indeed, the women survivors giving testimony at inquiries, revealing their experiences in the media, coming together to advocate for and on behalf of each other in recent years exhibit a defiance of a systemic church- and state-sponsored shaming that was accepted, if not endorsed, by Irish society for far too long.

Despite shame's inducement to hide, these women came out of hiding to name and seek redress for the injustices they endured. In this sense, shame, and their shared experiences of being shamed, perhaps constituted a point of connection, involving a shared understanding of circumstances, places, and histories that are similarly felt. This would bear out Sally Munt's (2008) and Elspeth Probyn's (2005) conception of shame as a force that unites us, might even provide glimpses into our common humanity, and entails agency. Given what I have said previously about shame's postremediality, wherein covering forms the sole response to one's exposed inadequacy, shared feeling per se is likely to entail recognition and to be a

${ }^{30}$ Ferriter (2012) provides some personal accounts of passion in Ireland that run counter to the dominant story of repression and misery. 
driver, among others, for action by groups of people who are shamed. Probyn (2005, xiii) makes the case for a constructive role for shame, arguing that "shame compels an involuntary and immediate reassessment of ourselves: Why am I ashamed? Why did I say or do that? Can I rectify the actions that have either brought shame upon myself or caused someone else's shame?" It seems to me that the value to be found in such self-assessment lies not in the experience of shame itself but rather in the questioning of one's emotional responses. Such questioning - particularly by those routinely shamed in our societies by virtue of their gender, race, or class, for instance-need not be immediate, and may not necessarily take place at all, as shame becomes internalized, forming part of gendered, racialized, and classed subjectivities. ${ }^{31}$ The extent and variety of women's resistance to shame as a disciplining device are therefore all the more remarkable in a context where women were ubiquitously constructed as bearers of the nation's moral purity, and as constant threats to that purity and thereby to the national identity itself.

In 2013, activism by survivors and advocates ultimately resulted in the McAleese inquiry, a redress scheme, and a state apology. In an acknowledgment of the shame borne by the Magdalen survivors, the Taoiseach declared in his speech: "What we address today is how you took this country's terrible 'secret' and made it your own. Burying it, carrying it in your hearts here at home, or with you to England and to Canada, America and Australia on behalf of Ireland and the Irish people. But from this moment on you need carry it no more, because today, we take it back. Today we acknowledge the role of the state in your ordeal" (in Irish Examiner 2013).

This apology is a welcome and long fought-for recognition of the harms done, a public acknowledgment of injustices committed by the state, which, in a remarkable turnaround, describes the Magdalen survivors' experiences as "a national shame." These women have thus gone from constituting instances of national shame to being survivors of an unjust and repressive state and society that allowed a system of national shame to "stereotyp[e]" and "fai[l]" them. Sadly, the Taoiseach's speech runs afoul of the classic demarcations of a shameful past, where a morally dubious, problematic history becomes displaced by an enlightened, virtuous present. ${ }^{32}$ In light of the Taoiseach's own assertion that "it would be easy to explain away all that happened" (Irish Examiner 2013), it is

${ }^{31}$ Calls for the inversion of shame with pride may therefore risk a hollow "denial of shame that confirms and consolidates its invidious power" (Valente 2005, 80).

32 This phenomenon is vividly traced by Sara Ahmed (2004) in the Australian context. 
incumbent upon feminists to ensure that such explaining away does not go unremarked and that the shaming of gendered others continues to be met with resistance in the Ireland of today. ${ }^{33}$

Gender Institute

London School of Economics and Political Science

\section{References}

Ahmed, Sara. 2004. The Cultural Politics of Emotion. Edinburgh: Edinburgh University Press.

Bacik, Ivana. 2015. "A Feminist Review of the Law on Abortion." In Irish Feminisms: Past, Present and Future, ed. Clara Fischer and Mary McAuliffe, 147-68. Dublin: Arlen House.

Clough, Patricia Ticineto, ed. 2007. The Affective Turn: Theorizing the Social. Durham, NC: Duke University Press.

Cork Examiner. 1925. "Statement of Irish Bishops' Meeting." Cork Examiner, November 30.

Cox, Catherine. 2009. "Institutionalisation in Irish History and Society." In Palgrave Advances in Irish History, ed. Mary McAuliffe, Katherine O’Donnell, and Leeann Lane, 169-90. New York: Palgrave Macmillan.

Crowley, Una, and Rob Kitchin. 2008. "Producing 'Decent Girls': Governmentality and the Moral Geographies of Sexual Conduct in Ireland." Gender. Place and Culture: A Iournal of Feminist Geoaraphy 15(4):355-72.

Currier, Ashley. 2012. "The Aftermath of Decolonization: Gender and Sexual Dissidence in Postindependence Namibia." Sians: Iournal of Women in Culture and Societs 37(2):441-67.

Ferriter, Diarmaid. 2012. Occasions of Sin: Sex and Society in Modern Ireland. London: Profile.

Finnegan, Frances. 2004. Do Penance or Perish: Magdalen Asylums in Ireland. Oxford: Oxford University Press.

Foucault, Michel. 2001. Madness and Civilization: A History of Insanity in the Age of Reason. Translated by Richard Howard. Abingdon: Routledge.

${ }^{33}$ Currently the Irish state is, for instance, overseeing a system of "direct provision" where asylum seekers are held, often for years, in reception centers that have been roundly critiqued by human rights bodies, civil society organizations, and, most recently, the Health Information and Quality Authority (see HIQA 2015). The culture of containment and shaming continues. With regard to the specific shaming of women, there has been an extraordinary blindness to the legacy of normative assumptions around parenting and family structure. Under the banner of "austerity," the government has enacted a series of cuts to state supports for lone parent family households, the vast majority of which are headed by women, with the result that lone parent households' deprivation levels have increased to a staggering 63 percent (Murphy 2015). 
Garrett, Paul Michael. 2000. “The Abnormal Flight: The Migration and Repatriation of Irish Unmarried Mothers." Social History 25(3):330-43.

Gregg, Melissa, and Gregory J. Seigworth, eds. 2010. The Affect Theory Reader. Durham, NC: Duke University Press.

Hanson, Ellis. 1997. Decadence and Catholicism. Cambridge, MA: Harvard University Press.

Hemmings, Clare. 2005. "Invoking Affect: Cultural Theory and the Ontological Turn." Cultural Studies 19(5):548-67.

Henchy, Seamus. (1966) 2012. "Commission of Inquiry on Mental Illness." In O'Sullivan and O'Donnell 2012, 92-97.

HIQA (Health Information and Quality Authority). 2015. "Findings of HIQA Inspection of the Child Protection and Welfare Services Provided to Children Living in Direct Provision Raises Serious Concerns.” Press release, May 25. http://www.hiqa.ie/press-release/2015-05-25-findings-hiqa-inspection-child -protection-and-welfare-services-provided-chi.

Howes, Marjorie. 2002. “Tradition, Gender, and Migration in 'The Dead,' or: How Many People Has Gretta Conroy Killed?” Yale Iournal of Criticism 15(1):149-71.

Inglis, Tom. 1997. "Foucault, Bourdieu and the Field of Irish Sexuality." Irish Journal of Sociology, no. 7: 5-28.

Irish Examiner. 2013. "Full Text of Enda Kenny's Apology to the Magdalene Laundries Survivors." Irish Examiner, February 19. http://www.irishexaminer .com/breakingnews/ireland/full-text-of-enda-kennys-apology-to-the-magdalene -laundries-survivors-585372.html.

Irish Independent. 1925. "Sermon by Archbishop Gilmartin." Irish Independent, May 12.

Irish Government. (1927) 2012. "Commission on the Relief of the Sick and the Destitute Poor, including the Insane Poor, 1927.” In O'Sullivan and O'Donnell 2012, 63-73.

. 2015. "Commission of Investigation (Mother and Baby Homes and Certain Related Matters).” http://www.dcya.gov.ie/documents/Mother_and_Baby _Homes/20150109DraftOrderCommofInvestigation.pdf.

Jaggar, Alison M. 1992. "Love and Knowledge: Emotion in Feminist Epistemology." In Women and Reason, ed. Elizabeth D. Harvey and Kathleen Okruhlik, 115-42. Ann Arbor: University of Michigan Press.

Locke, Jill. 2007. "Shame and the Future of Feminism." Hypatia 22(4):146-62.

Luddy, Maria. 1995. Women and Philanthropy in Nineteenth-Century Ireland. Cambridge: Cambridge University Press.

- 2007a. Prostitution and Irish Society, 1800-1940. Cambridge: Cambridge University Press.

- 2007b. "Sex and the Single Girl in 1920s and 1930s Ireland." Irish Review 35 (Summer): 79-91.

MacInerny, Humbert. (1925) 2012. "A Plea for Social Service: The Irish Rosary." In O'Sullivan and O'Donnell 2012, 59-62. 
The Magdalene Sisters. 2002. Directed by Peter Mullan. Dublin: A PFP Films Production in association with Temple Films.

McAleese, Martin. 2013. "Report of the Inter-Departmental Committee to Establish the Facts of State Involvement with the Magdalen Laundries (The McAleese Report)." http://www.justice.ie/en/JELR/Pages/MagdalenRpt2013.

McAuliffe, Mary. 2009. "Irish Histories: Gender, Women and Sexualities." In Palgrave Advances in Irish History, ed. Mary McAuliffe, Katherine O'Donnell, and Leeann Lane, 191-221. New York: Palgrave Macmillan.

McCarthy, Rebecca Lea. 2010. Origins of the Magdalen Laundries: An Analytical History. London: McFarland.

McClintock, Anne. 1993. "Family Feuds: Gender, Nationalism and the Family." Feminist Review, no. 44: 61-80.

McGettrick, Claire. 2014. "Magdalene Survivors Are Still Seeking Justice." Irish Examiner, July 14. http://www.irishexaminer.com/viewpoints/analysis/mag dalene-survivors-are-still-seeking-justice-275291.html.

- 2015. "Death, Institutionalisation and Duration of Stay: A Critique of Chapter 16 of the Report of the Inter-Departmental Committee to Establish the Facts of State Involvement with the Magdalen Laundries and Related Issues." Report, JFM Research. http://www.magdalenelaundries.com/JFMR _Critique_190215.pdf.

Miller, Kerby. 1990. "Emigration, Capitalism and Ideology in Post-Famine Ireland." In Migrations: The Irish at Home and Abroad, ed. Richard Kearney, 91108. Dublin: Wolfhound.

Munt, Sally R. 2008. Queer Attachments: The Cultural Politics of Shame. Aldershot: Ashgate.

Murphy, Francis, Helen Buckley, and Larain Joyce. 2005. The Ferns Report. Dublin. http://www.bishop-accountability.org/reports/2005_10_Ferns/Complete _Ferns_Report_SO.pdf.

Murphy, Mary. 2015. “Lone Parents Want to Work.” Village, May 20. http:// www.villagemagazine.ie/index.php/2015/05/lone-parents-want-to-work/.

Murphy, Yvonne. 2010a. Commission of Investigation, Report into the Catholic Archdiocese of Dublin (the Murphy [Dublin] Report). http://www.bishop -accountability.org/reports/2009_11_26_Murphy_Report/\#report.

_ 2010b. "Commission of Investigation, Report into the Catholic Diocese of Cloyne" (the Cloyne Report). http://www.justice.ie/en/JELR/Pages/Cloyne Rpt.

Najafi, Sina, David Serlin, and Lauren Berlant. 2008. "The Broken Circuit: An Interview with Lauren Berlant." Cabinet, no. 31. http://www.cabinetmaga zine.org/issues/31/najafi_serlin.php.

Nussbaum, Martha C. 2004. Hiding from Humanity: Disgust, Shame, and the Law. Princeton, NJ: Princeton University Press.

Ó Fátharta, Conall. 2013. "UN Anti-torture Body Criticises Magdalenes Report." Irish Examiner, June 1. http://www.irishexaminer.com/ireland/un-anti -torture-body-criticises-magdalenes-report-233047.html. 
O'Sullivan, Eoin, and Ian O'Donnell, eds. 2012. Coercive Confinement in Ireland: Patients, Prisoners and Penitents. Manchester: Manchester University Press.

Philomena. 2013. Directed by Stephen Frears. A coproduction of BBC Films, Baby Cow Productions, BFI, Magnolia Mae Films, and Pathé.

Probyn, Elspeth. 2005. Blush: Faces of Shame. Minneapolis: University of Minnesota Press.

Redmond, Jennifer. 2008. “'Sinful Singleness'? Exploring the Discourses on Irish Single Women's Emigration to England, 1922-1948." Women's Historv Review $17(3): 455-76$.

Reidy, Conor. 2009. Ireland's "Moral Hospital": The Irish Borstal System, 19061956. Dublin: Irish Academic Press.

RTÉ One. 2015. "The Tuam Babies.” Would You Believe?, April 12. http://www .rte.ie/tv/wouldyoubelieve/av_index.html.

Ryan, Louise. 2002. "Sexualising Emigration: Discourses of Irish Female Emigration in the 1930s." Women's Studies International Forum 25(1):51-65.

Ryan, Sean. 2009. "Report of the Commission to Inquire into Child Abuse" (the Ryan Report). http://www.childabusecommission.ie/publications/index.html.

Sagart [Priest]. (1922) 2012. "How to Deal with the Unmarried Mother." In O'Sullivan and O'Donnell 2012, 45-51.

Smith, James M. 2004. "The Politics of Sexual Knowledge: The Origins of Ireland's Containment Culture and the Carrigan Report (1931)." Iournal of the History of Sexuality 13(2):208-33.

- 2007a. Ireland's Magdalen Laundries and the Nation's Architecture of Containment. Manchester: Manchester University Press.

—. 2007b. "The Magdalene Sisters: Evidence, Testimony . . Action?” Signs $32(2): 431-58$.

Thane, Pat, and Tanya Evans. 2012. Sinners? Scroungers? Saints? Unmarried Motherhood in Twentieth-Century England. Oxford: Oxford University Press.

Valente, Joseph. 2005. "Race/Sex/Shame: The Queer Nationalism of At Swim Two Boys." Éire-Ireland 40(3-4):58-84.

Valiulis, Maryann. 1995a. "Neither Feminist nor Flapper: The Ecclesiastical Construction of the Ideal Irish Woman." In Chattel, Servant or Citizen, ed. Mary O'Dowd and Sabine Wichert, 168-78. Belfast: Institute of Irish Studies, Queens University of Belfast.

- 1995b. "Power, Gender, and Identity in the Irish Free State." Iournal of Women's History 6(4):117-36.

Warner, Michael. 1999. The Trouble with Normal: Sex, Politics, and the Ethics of Queer Life. Cambridge, MA: Harvard University Press.

Williams, Bernard. 2008. Shame and Necessity. Berkeley: University of California Press. 